\title{
Effect of Insulinlike Growth Factor I on DNA and Protein Synthesis in Cultured Rat Calvaria
}

\author{
Ernesto Canalis, Endocrine Section, Department of Medicine, \\ Saint Francis Hospital and Medical Center, Hartford, Connecticut 06105; \\ Department of Medicine, University of Connecticut Health Center, \\ Farmington, Connecticut 06032
}

A B S T R A C T Insulinlike growth Factor I (IGF I), a growth hormone-dependent peptide or somatomedin, was studied for its effects on bone formation by examining the synthesis of DNA, collagen, and noncollagen protein in cultures of 21-d fetal rat calvaria.

IGF I caused a dose-dependent stimulation of the incorporation of $\left[{ }^{3} \mathrm{H}\right]$ thymidine into DNA at concentrations of $0.1-100 \mathrm{nM}$; the effect appeared after $6 \mathrm{~h}$, was maximal at $12 \mathrm{~h}$, and was sustained for $96 \mathrm{~h}$. IGF I also increased the bone DNA content. IGF I at 0.1-3 nM had a small stimulatory effect on the incorporation of $\left[{ }^{3} \mathrm{H}\right]$ proline into collagenase-digestible protein (CDP) whereas 30 nM IGF I caused a two- to threefold increment and had a maximal effect. A smaller effect on the labeling of noncollagen protein (NCP) was also observed. The effect of CDP and NCP appeared and was maximal after $12 \mathrm{~h}$ and was sustained for $96 \mathrm{~h}$. IGF I increased the total collagen content of bones. The IGF I stimulatory effect on the incorporation of $\left[{ }^{3} \mathrm{H}\right]$ thymidine was seen in both the periosteum and periosteumfree calvarium, whereas that on the labeling of CDP was seen only in the central, osteoblastic-rich, nonperiosteal bone. Histological sections showed a 10-fold increase in the mitotic index after Colcemid arrest in IGF I-treated bones; the mitoses were equally distributed in the periosteum and central portions of the calvarium.

Insulin had a stimulatory effect on the incorporation of $\left[{ }^{3} \mathrm{H}\right]$ proline into CDP and NCP at $1 \mathrm{nM}-1 \mu \mathrm{M}$ similar to the effect of IGF I. In contrast, high insulin concentrations ( 0.1 and $1 \mu \mathrm{M})$ were required to increase the incorporation of $\left[{ }^{3} \mathrm{H}\right]$ thymidine, and insulin did not affect DNA content. Cortisol decreased the stimulatory effect of IGF I on DNA labeling but greatly enhanced the stimulatory effect of IGF I on the incorporation of $\left[{ }^{3} \mathrm{H}\right]$ proline into CDP. Triiodothyronine and parathy-

Received for publication 14 January 1980 and in revised form 16 June 1980. roid hormone increased the incorporation of $\left[{ }^{3} \mathrm{H}\right]$ thymidine and were additive to IGF I. Triiodothyronine did not affect the labeling of CDP, but parathyroid hormone inhibited it and opposed the effect of IGF I.

These studies indicate that IGF I stimulates bone DNA, collagen, and NCP synthesis in vitro. IGF I and insulin have similar effects on bone collagen synthesis but IGF I stimulates the synthesis of DNA at physiological concentrations, and insulin does not.

\section{INTRODUCTION}

Although there is a considerable amount of knowledge about the factors that regulate linear or cartilage-dependent growth, little is known about the control of bone formation. This is presumably dependent on many hormones; however, the humoral regulatory system for bone growth has not yet been fully elucidated. A number of agents have been shown to inhibit bone formation, but only insulin, multiplication stimulating activity (MSA), ${ }^{1}$ and a partially purified preparation of somatomedin were found to have a direct stimulatory effect on bone collagen synthesis (1-4).

Insulinlike growth Factor I (IGF I), a growth hormone-dependent single-chain peptide with a molecular weight of 7,649 and functionally identical to somatomedin $\mathrm{C}$, was recently isolated from human plasma (5-9). IGF I mimic's many of the known metabolic actions of insulin, but it is a more potent stimulator of cellular growth. The growth-promoting activities of IGF I have been recognized in various tissues and cell systems, including cartilage, chondrocytes, chick embryo, and human fibroblasts $(5,8,10-12)$. Its effects on bone formation have not yet been tested, however.

\footnotetext{
'Abbreviations used in this paper: CDP, collagenase-digestible protein; IBMX, isobutylmethylxanthine; IGF I, insulinlike growth Factor I; MSA, multiplication stimulating activity; NCP, noncollagenase protein; PTH, parathyroid hormone; $\mathrm{T}_{3}$, triiodothyronine.
} 
These studies extend and confirm previous investigations on the effects of a partially purified preparation of somatomedin $\mathrm{C}$ on bone (1). They were undertaken to assess the direct effects of a pure preparation of IGF I on bone DNA, collagen, and noncollagen protein (NCP) synthesis and compare them with the effects of insulin. In addition, we examined the interactions of IGF I with cortisol, parathyroid hormone (PTH), and triiodothyronine $\left(\mathrm{T}_{3}\right)$, known regulators of collagen synthesis and cell proliferation in bone (1.3-15).

\section{METHODS}

\section{Culture technique}

The method used to study effects on bone formation has been described in detail previously $(2,4)$. Half calvaria from 21-d fetal rats were cultured in sterile 25 -ml flasks containing $2 \mathrm{ml}$ of modified $\mathrm{BGJ}_{\mathrm{b}}$ medium (Gibco Laboratories, Grand Island Biological Co., Grand Island, N. Y. [16]) supplemented with bovine serum albumin $(4 \mathrm{mg} / \mathrm{ml}$, Reheis Chemical Co. Phoenix, Ariz.), $1 \mathrm{~m} . \mathrm{M}$ unlabeled proline, and $0.1 \mathrm{m.M}$ thymidine (14). The flasks were gassed with $5 \% \mathrm{CO}$. in air for $1 \mathrm{~min}$, sealed with rubber stoppers, and placed in a continuously shaking water bath $(40$ oscillations $/ \mathrm{min})$ at $37^{\circ} \mathrm{C}$ for periods of $0-96 \mathrm{~h}$.

A pure preparation of IGF I was kindly provided by Dr. R. E. Humbel, Zurich, Switzerland. IGF I was isolated from an acid ethanol extract of a Cohn fraction from human plasma by gel filtration, ion exchange chromatography, and polyacrylamide gel electrophoresis $(5,6)$. IGF I, synthetic bovine PTH (Beckman Instruments Inc., Spinco Div., Palo Alto, Calif.), and isobutylmethylxanthine (IBMX, Calbiochem-Behring Corp., American Hoechst Corp., La Jolla, Calif.) were added directly to $\mathrm{BGJ}_{\mathrm{b}}$ medium. Crystalline porcine insulin (Eli Lilly \& Co.; Indianapolis, Ind.) was dissolved in $0.00 .5 \mathrm{~N} \mathrm{HCl}$ and diluted $1: 100$ or greater in BGJ. Cortisol (Sigma Chemical Co., St. Louis, Mo.) was dissolved in absolute alcohol and then diluted 1: 100,000 in BGJ. $T_{3}$ was dissolved in a basic alcoholic solution and then diluted 1:10,000 or greater in BGJ. The agents studied were present in the culture medium throughout the incubation period, except in the time-course experiments. For these experiments, all bones, treated and control, were cultured for $24 \mathrm{~h}$, and IGF was added at appropriate times before the end of the culture period.

\section{DNA synthesis}

DNA synthesis was studied by examining effects on the incorporation of $\left[{ }^{3} \mathrm{H}\right]$ thymidine and on total DNA content.

$\left[{ }^{3} H\right]$ Thymidine labeling. Calvaria were incubated and thymidine methyl- ${ }^{3} \mathrm{H}(5 \mu \mathrm{Ci} / \mathrm{ml}$; specific activity $65-80 \mathrm{Ci} / \mathrm{mmol}$; ICN (Chemical and Radioisotope Div., Irvine, Calif.) was added during the last $60 \mathrm{~min}$ of the culture period. At the end of the incubation, calvaria were washed with cold $5 \%$ trichloroacetic acid, acetone, and ether; the bones were then dried and weighed, and the radioactivity incorporated determined after digesting them with NCS tissue solubilizer (Amersham Corp., Arlington Heights, Ill.). The acid-extractable pool was determined by measuring the radioactive counts in the trichloroacetic acid wash.

DNA content. To measure total DNA content, calvaria were extracted and homogenized; and DNA was measured according to a modification of the fluorometric method of Kissane and Robbins (17, 18).

\section{Collagen and noncollagen protein synthesis}

$\left[{ }^{3} \mathrm{H}\right]$ Proline labeling. Labeled proline $\left(2,3{ }^{3} \mathrm{H}, 5 \mu \mathrm{Ci} / \mathrm{ml}\right.$; specific activity $20-30 \mathrm{Ci} / \mathrm{mmol}$; New England Nuclear, Boston, Mass.) was added for the last $2 \mathrm{~h}$ of the culture period. The calvaria were extracted, weighed, and homogenized; and an aliquot was incubated with repurified bacterial collagenase (Worthington Biochemical Corp., Freehold, N. J.). The enzyme preparation used was repurified on a G-200 Sephadex column and did not contain any proteolytic activity on noncollagen substrates (Tryptophan-labeled bones). The labeled proline incorporated into collagenase-digestible protein (CDP) and NCP was measured according to the method of Peterkofsky and Diegelmann (19). Percent collagen synthesis was calculated after multiplying NCP by 5.4 to correct for the relative abundance of proline in CDP and NCP. This was based on previous observations by Peterkofsky $(20)$.

To determine the proportion of newly synthesized collagen released from the bone into the medium, aliquots of the medium were exhaustively dialyzed in Spectrapor No. 3 dialysis tubing (Spectrum Medical Industries, Inc., Los Angeles, Calif.; assigned molecular weight cutoff of $3,50(0)$ against 0.5 $M$ acetic acid and analyzed for labeled CDP. The CDP in the medium was expressed as percent of total newly synthesized collagen.

Collagen content. To determine the total bone collagen content, calvaria were extracted and homogenized, and hydroxyproline was measured according to a modification of the method of Cheng (21). The collagen content was calculated by multiplying the hydroxyproline content by 7.09 (22).

\section{Effects on periosteum and periosteum-free calvaria}

These experiments were performed to compare humoral effects on periosteal tissue, which is rich in fibroblasts and precursor cells, and on the remainder of the calvarium, located in the central portion of the bone, which consists largely of bone tissue, is rich in osteoblasts, and is referred to as "periosteum-free calvarium" (23-26). Intact bones were cultured for $24 \mathrm{~h}$ and $\left[{ }^{3} \mathrm{H}\right]$ thymidine or $\left[{ }^{3} \mathrm{H}\right]$ proline was added for the last 60 or $120 \mathrm{~min}$, respectively. Calvaria were then washed with $0.9 \%$ saline solution, and the periosteum was removed from the superior and inferior surfaces with a scalpel blade. The incorporation of $\left[{ }^{3} \mathrm{H}\right]$ thymidine into acid-insoluble extracts and of $\left[{ }^{3} \mathrm{H}\right]$ proline into CDP and NCP were independently determined in the superior and inferior periosteum and in the central bone or periosteum-free calvarium.

\section{Histology}

To study the effect of IGF I on bone morphology and cell mitosis, calvaria were cultured and n-desacetyl-n-methyl colchicine (Colcemid, $4 \mu \mathrm{M}$; Gibco Laboratories, Grand Island Biological Co., Grand Island, N. Y.) was added for the last $3 \mathrm{~h}$ of the culture period. Calvaria were fixed in neutral formalin, embedded in paraffin, and stained with hematoxylineosin. Mitoses were counted in random cross sections taken from four control and five IGF-treated bone explants.

\section{Statistical methods}

Data are expressed as mean $\pm \mathrm{SE}$ of disintegrations per minute per microgram extracted dry weight, disintegrations per half calvaria, and percent collagen synthesis. DNA and collagen content are expressed as micrograms per half calvaria. Statistical differences were analyzed using Student's $t$ test. 


\section{TABLE I}

Time-course for Incorporation of $\left[{ }^{3} \mathrm{H}\right]$ Thymidine into Acid-insoluble Residues, DNA Content, and Mitotic Index in Calvaria Cultured in Control (BGJ) Medium in the Absence of Hormones

\begin{tabular}{cccc}
\hline Culture period & $\begin{array}{c}\left.{ }^{3} \mathrm{H}\right] \text { Thymidine } \\
\text { incorporation }\end{array}$ & DNA content & $\begin{array}{c}\text { Mitoses per } \\
\text { histologic section }\end{array}$ \\
\hline$h$ & $d p m / \mu g d r y w t$ & $\mu g /$ half calvaria & \\
0 & - & $10.9 \pm 1.5$ & - \\
3 & $7.6 \pm 0.2$ & $10.9 \pm 2.0$ & $<2$ \\
6 & $6.9 \pm 0.3$ & $13.5 \pm 1.0$ & $<2$ \\
12 & $3.6 \pm 0.3$ & $10.9 \pm 0.2$ & $<2$ \\
24 & $8.5 \pm 1.2$ & $12.4 \pm 1.1$ & $<2$ \\
\hline
\end{tabular}

Values are means $\pm \mathrm{SE}$ for five half calvaria cultured for $0-24 \mathrm{~h}$ in BGJ medium. Bones were cultured only for the indicated times and treated with $\left[{ }^{3} \mathrm{H}\right]$ thymidine for the last $60 \mathrm{~min}$ or with Colcemid for the last $3 \mathrm{~h}$ of the incubation period.

\section{RESULTS}

DNA synthesis. The incorporation of $\left[{ }^{3} \mathrm{H}\right]$ thymidine into acid-insoluble residues, the DNA content, and the number of mitoses per histological section after colcemid in calvaria incubated in the absence of hormones were similar after 0 (or 3 ) to $24 \mathrm{~h}$ of culture (Table I).
There was a $50 \%$ decrease in the incorporation of $\left[{ }^{3} \mathrm{H}\right]-$ thymidine after $12 \mathrm{~h}$ of culture, which was concomitant with a decrease of similar magnitude on the uptake of the label into the acid-extractable pool (data not shown).

After $24 \mathrm{~h}$ of culture in the presence of IFG I, there was an increase in the incorporation of $\left[{ }^{3} \mathrm{H}\right]$ thymidine into the acid-insoluble fraction of cultured calvaria of 24-164\%. In contrast, IGF I did not increase significantly the uptake of the label into the acid-extractable pool $(-5-15 \%)$. The dose-response curve demonstrated two effects, one observed at concentrations of 0.01-3 nM, which was small and not clearly dose related, and another, marked and dose related, observed at $10-100 \mathrm{nM}$ (Fig. 1). Concentrations $<0.01 \mathrm{nM}$ were not effective, and the greatest effect occurred at 100 $\mathrm{nM}$, which was the highest dose tested. The time-course of the IGF I effect on $\left[{ }^{3} \mathrm{H}\right]$ thymidine incorporation was studied by adding $10 \mathrm{nM}$ IGF I at various times before the end of the culture period in an experiment where all bones (IGF I-treated and control) were cultured for $24 \mathrm{~h}$. Treatment with IGF I for $1.5-3 \mathrm{~h}$ did not alter the incorporation of $\left[{ }^{3} \mathrm{H}\right]$ thymidine. Thereafter, the effect steadily increased, and it was maximal after $12 \mathrm{~h}$ (Fig. 2 ). The stimulatory effect of IGF I was sustained for $96 \mathrm{~h}$. The incorporation of $\left[{ }^{3} \mathrm{H}\right]$ thymidine in calvaria cultured in control medium was $9.2 \pm 0.9 \mathrm{dpm} / \mu \mathrm{g}$ (mean $\pm \mathrm{SE} ; n=6)$ and it was increased to $17.2 \pm 2.0 \mathrm{dpm} / \mu \mathrm{g}$

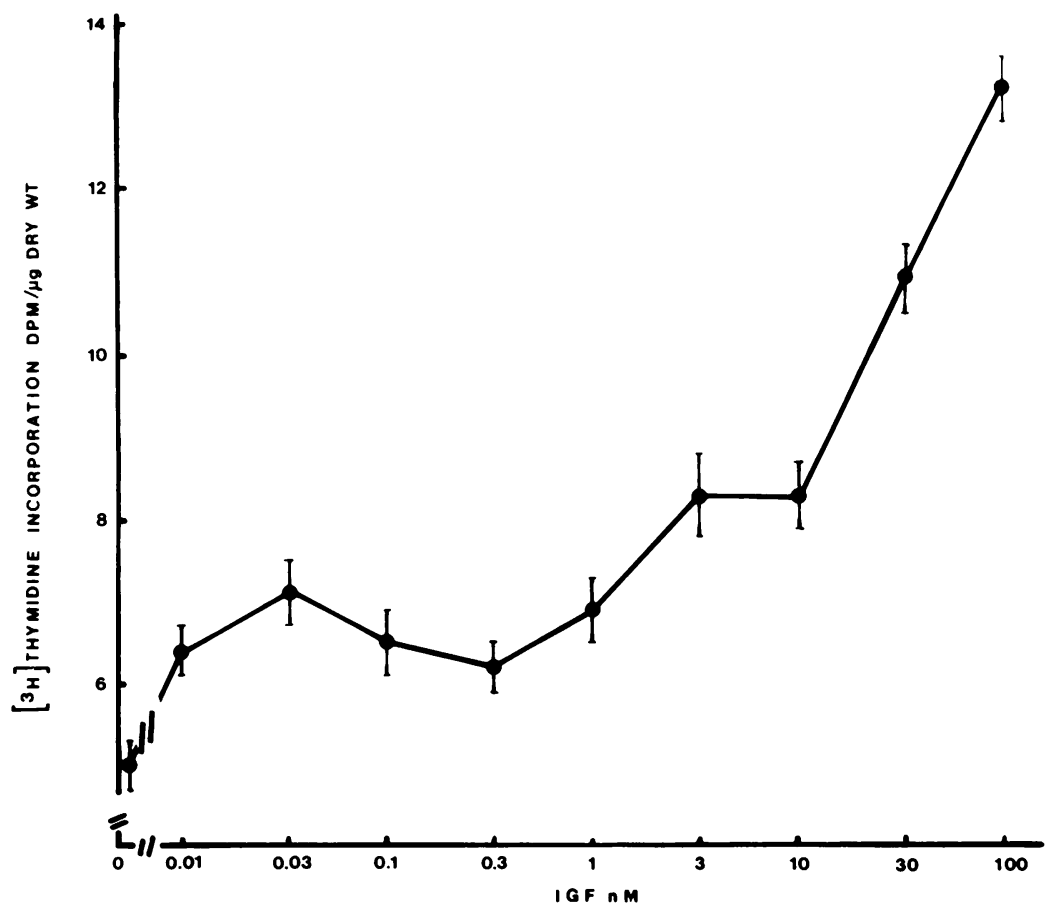

FIGURE 1 Effect of IGF I on the incorporation of $\left[{ }^{3} \mathrm{H}\right]$ thymidine into fetal rat calvaria. Symbols represent mean values, and vertical lines represent $\mathrm{SE}$ for five half calvaria cultured for $24 \mathrm{~h}$ in the presence of IGF I and pulsed with $\left[{ }^{3} \mathrm{H}\right]$ thymidine for the last $60 \mathrm{~min}$ (IGF I concentrations are plotted on a logarithmic scale). 


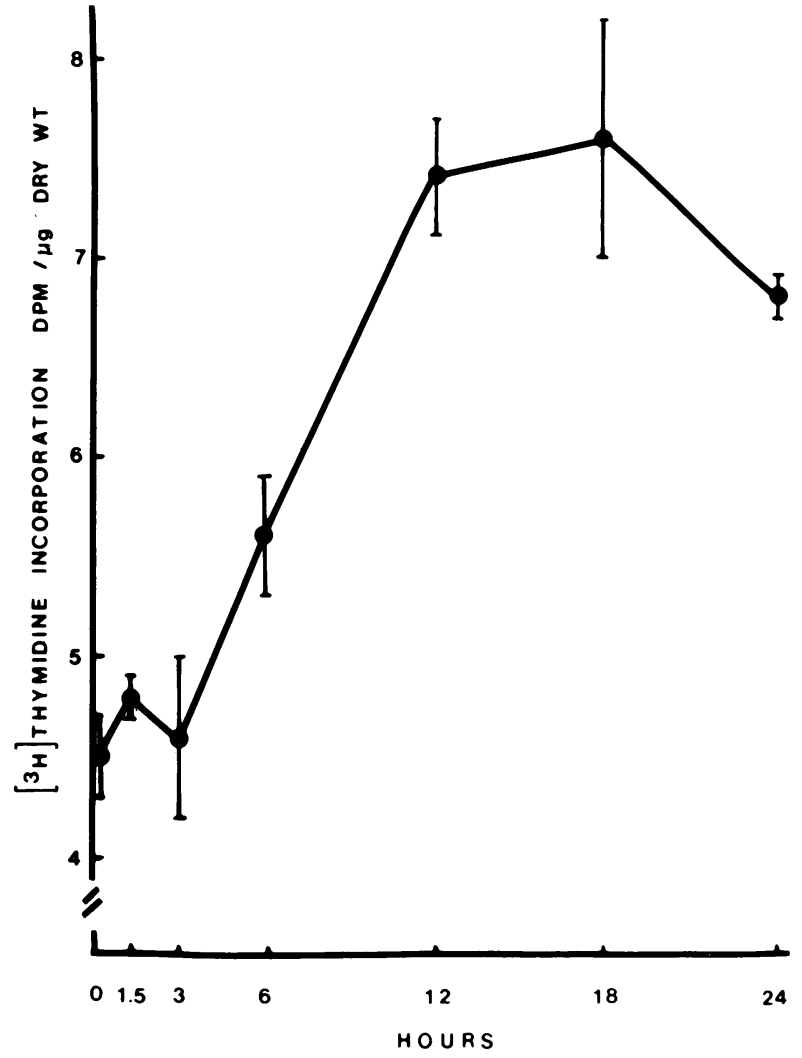

Figure 2 Time-course for the effect of $10 \mathrm{nM}$ IGF I on the incorporation of $\left[{ }^{3} \mathrm{H}\right]$ thymidine into fetal rat calvaria. Symbols represent mean values, and vertical lines represent $\mathrm{SE}$ for five half calvaria cultured for $24 \mathrm{~h}$ and pulsed with $\left[{ }^{3} \mathrm{H}\right]$ thymidine for the last $60 \mathrm{~min}$. IGF I was present only for the indicated times before the end of the culture period.

$(P<0.01)$ in calvaria cultured for $96 \mathrm{~h}$ in the continuous presence of IGF I at $10 \mathrm{nM}$.

The DNA content of cultured calvaria was increased by IGF I. Bones cultured in control medium for $24 \mathrm{~h}$ contained $12.4 \pm 1.3($ mean $\pm \mathrm{SE} ; n=5) \mu \mathrm{g}$ DNA/half calvaria whereas bones cultured with IGF I at a concentration of $10 \mathrm{nM}$ contained $19.6 \pm 2.5 \mu \mathrm{g} \mathrm{DNA} / \mathrm{half}$ calvaria $(P<0.02)$.

Collagen and NCP synthesis. The incorporation of $\left[{ }^{3} \mathrm{H}\right]$ proline into CDP in calvaria cultured in medium without added hormones was highest after $3 \mathrm{~h}$ of incubation; thereafter, a time-dependent decline was observed up to $12 \mathrm{~h}$ of culture (Table II). The incorporation of $\left[{ }^{3} \mathrm{H}\right]$ proline into NCP and the bone collagen content were unchanged from 0 to $24 \mathrm{~h}$ of culture. While IGF increased the labeling of CDP compared with control bones cultured for $24 \mathrm{~h}$, this effect was smaller than the values observed in control bones cultured for 3-h periods.

After $24 \mathrm{~h}$ of culture, IGF I caused a dose-related stimulation of the incorporation of $\left[{ }^{3} \mathrm{H}\right]$ proline into
TABLE II

Time-course for Incorporation of $\left[{ }^{3} \mathrm{H}\right]$ Proline into CDP and NCP, and Total Collagen Content in Calvaria Cultured in Control (BGJ) Medium

\begin{tabular}{cccccc}
\hline Treatment & CIP & NCP & $\begin{array}{c}\text { Collagen } \\
\text { svinthesis }\end{array}$ & $\begin{array}{c}\text { Collagen } \\
\text { content }\end{array}$ \\
\hline \multirow{4}{*}{ Control } & $h$ & $d p m / \mu g d r ! c t$ & $\%$ & $\mu g / h a l f$ calt aria \\
& 0 & - & - & - & $132 \pm 7$ \\
& 3 & $81 \pm 1$ & $48 \pm 3$ & $25.1 \pm 0.6$ & $150 \pm 10$ \\
& 6 & $61 \pm 4$ & $43 \pm 1$ & $20.7 \pm 0.7$ & $152 \pm 14$ \\
& 12 & $31 \pm 4$ & $39 \pm 3$ & $12.8 \pm 0.6$ & $142 \pm 10$ \\
IGF I & 24 & $32 \pm 3$ & $44 \pm 2$ & $12.0 \pm 0.4$ & $155 \pm 7$ \\
\hline
\end{tabular}

Values are means \pm SE for 5-10 half calvaria cultured for ()-24 $\mathrm{h}$ in BGJ medium or for $24 \mathrm{~h}$ with $30 \mathrm{nM}$ IGF. Bones were cultured only for the indicated times and treated with $\left[{ }^{3} \mathrm{H}\right]$ proline for the last $2 \mathrm{~h}$ of the incubation period. Percent collagen was corrected for the relative abundance of proline in CDP and NCP.

* Significantly different from control cultured for $24 \mathrm{~h}, P<0.05$.

CDP. Concentrations of $0.1-3 \mathrm{nM}$ had a small but significant effect. Similar to the effect on $\left[{ }^{3} \mathrm{H}\right]$ thymidine incorporation, IGF I concentrations of $10-100 \mathrm{nM}$ had a more pronounced effect on the labeling of CDP. The IGF I effect was maximal at a concentration of $30 \mathrm{nM}$, which increased the incorporation of $\left[{ }^{3} \mathrm{H}\right]$ proline into CDP by two- to threefold (Fig. 3). The labeling of NCP was also increased, but the effect on the labeling of CDP was proportionally greater, so that the percent collagen synthesized was significantly increased in the IGF I-treated calvaria (Table III). The time-course of the effect of IGF I on the labeling of CDP and NCP was studied by adding $10 \mathrm{nM}$ IGF I at various times before the end of a 24 -h culture. The IGF I stimulatory effect on the incorporation of $\left[{ }^{3} \mathrm{H}\right]$ proline into CDP and NCP appeared and was maximal after $12 \mathrm{~h}$ (Fig. 4). The effect was sustained for $96 \mathrm{~h}$. The incorporation of $\left[{ }^{3} \mathrm{H}\right]$ proline into CDP and NCP in calvaria cultured for $96 \mathrm{~h}$ in control medium was $53 \pm 7$ and $5.3 \pm 4 \mathrm{dpm} / \mu \mathrm{g}$ (mean $\pm \mathrm{SE} ; n=6$ ); the respective values in bones cultured in the continuous presence of IGF I at $10 \mathrm{nM}$ were $81 \pm 6(P<0.02)$ and $72 \pm 6 \mathrm{dpm} / \mu \mathrm{g}(P<0.05)$.

The effect of IGF I was similar at low $(1 \mu \mathrm{M})$ and high $(1 \mathrm{mM})$ medium proline concentrations (Table III), and could not be ascribed to decreased release of CDP to the culture medium. During the 2 -h pulse, $5.4 \pm 0.2 \%$ (mean $\pm \mathrm{SE} ; n=5$ ) of the total newly synthesized collagen was released into the medium of IGF I-treated calvaria, whereas $6.6 \% \pm 0.5$ was released in control cultures.

IGF I increased the bone collagen content. Calvaria cultured in control medium for $24 \mathrm{~h}$ contained $129 \pm 6$ $($ mean $\pm \mathrm{SE} ; n=5) \mu \mathrm{g}$ collagen/half calvaria whereas 


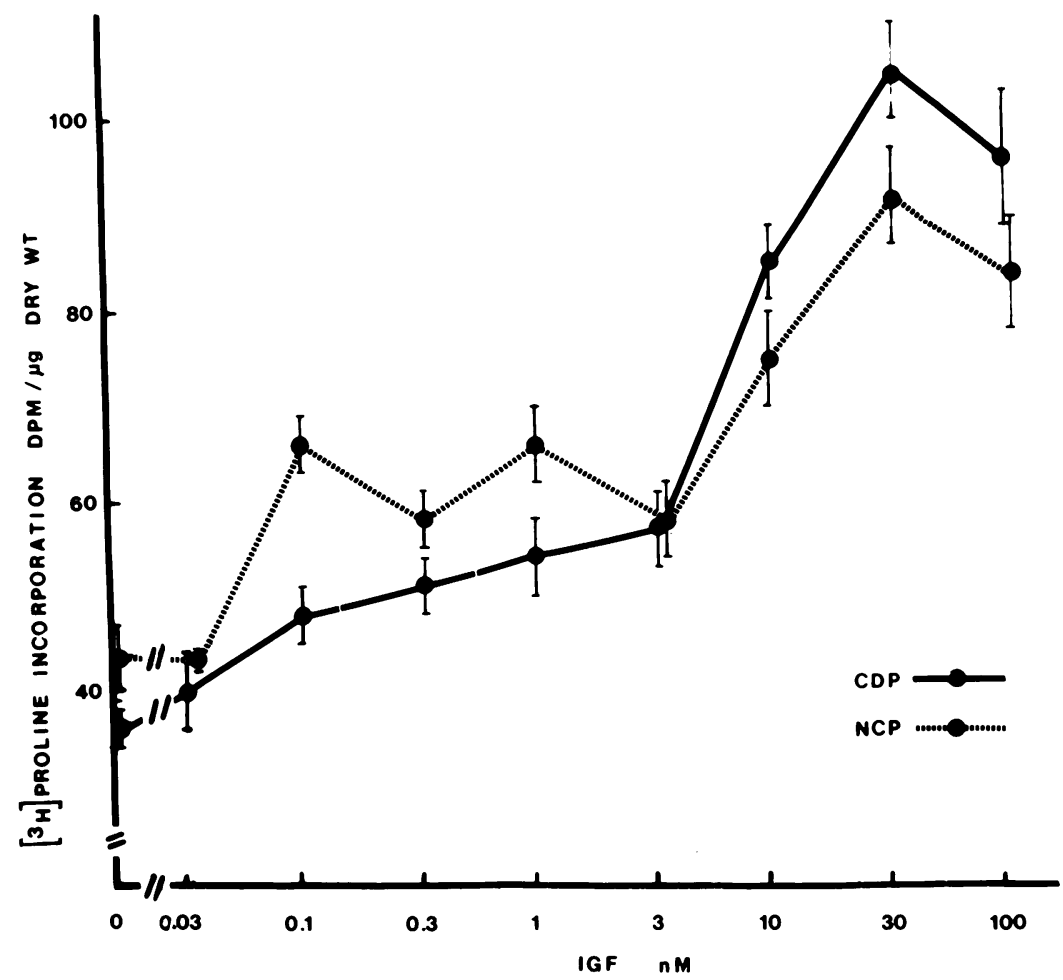

FIGURE 3 Effect of IGF I on the incorporation of $\left[{ }^{3} \mathrm{H}\right]$ proline into CDP and NCP. Symbols represent mean values, and vertical lines represent $\mathrm{SE}$ for five half calvaria cultured for $24 \mathrm{~h}$ in the presence of IGF I and pulsed with $\left[{ }^{3} \mathrm{H}\right]$ proline for the last $2 \mathrm{~h}$ (IGF concentrations are plotted on a logarithmic scale).

those cultured with IGF I $(100 \mathrm{nM})$ contained $185 \pm 6$ $\mu \mathrm{g} / \mathrm{half}$ calvaria $(P<0.01)$.

Effects on periosteum and periosteum-free calvaria. The incorporation of $\left[{ }^{3} \mathrm{H}\right]$ proline into CDP was significantly greater in the central portion of the bone or

TABLE III

Effect of IO n.M IGF I on Incorporation of $\left[{ }^{3} \mathrm{H}\right]$ Proline into CDP and NCP in Fetal Rat Calvaria Cultured in the Presence of 1 p.11 or 1 m.M Proline

\begin{tabular}{llcc}
\hline \multicolumn{1}{c}{ Treatment } & CDP & NCP & $\begin{array}{c}\text { Collagen } \\
\text { synthesis }\end{array}$ \\
\hline & \multicolumn{2}{c}{$d p m / \mu g d r y u t$} & $\%$ \\
$1 \mu$ M proline & & & \\
Control & $106 \pm 7$ & $153 \pm 6$ & $11.3 \pm 0.5$ \\
IGF I & $198 \pm 7^{*}$ & $176 \pm 6^{*}$ & $17.2 \pm 0.6^{*}$ \\
$1 \mathrm{mM}$ proline & & & \\
Control & $36 \pm 2$ & $43 \pm 4$ & $13.8 \pm 0.8$ \\
IGF I & $85 \pm 4^{*}$ & $75 \pm 5^{*}$ & $17.4 \pm 0.9^{*}$ \\
\end{tabular}

Values are means \pm SE for 5 half calvaria cultured for $24 \mathrm{~h}$ at the indicated proline concentrations in the presence or absence of IGF I and pulsed with $\left[{ }^{3} \mathrm{H}\right]$ proline for the last $2 \mathrm{~h}$. Percent collagen was corrected for the relative abundance of proline in CDP and NCP.

* Significantly different from control, $P<0 .(01$. periosteum-free calvarium than in the superior and inferior periosteal lavers in both control and treated bones. In contrast, the labeling of NCP was greater in the periostem than in the central bone (Table IV). Thus, the percent collagen synthesized was much larger in the periosteum-free (central) calvarium than in the periosteum. Similar to the labeling of NCP, most of the $\left[{ }^{3} \mathrm{H}\right]$ thymidine incorporated in calvaria $(\sim 80 \%)$ occurred in the periosteal layers, whereas only a small proportion was incorporated in the periosteum-free central bone. IGF I increased the incorporation of $\left[{ }^{3} \mathrm{H}\right]$ proline into CDP and the percent collagen synthesized in the periosteum-free calvarium, but not in the periosteal layers, whereas IGF I increased the incorporation of $\left[{ }^{3} \mathrm{H}\right]$ thymidine in the periosteal as well as in the nonperiosteal bone.

Histology. The number of mitoses per histologic section seen after $24 \mathrm{~h}$ of culture and $3 \mathrm{~h}$ of colcemid arrest was (mean $\pm \mathrm{SE} ; n=5) \quad 1.8 \pm 0.3$ in control and $17.6 \pm 1.6$ in $30 \mathrm{nM}$ IGF I-treated calvaria $(P<0.01)$. The stimulatory effect of IGF I on cell replication was of similar magnitude in the periosteum, rich in fibroblastic elongated cells, and in the central portions of the bone explant away from the periosteum, where rounded cells predominate. The number of mitoses in the superior and inferior periosteum in IGF I-treated 


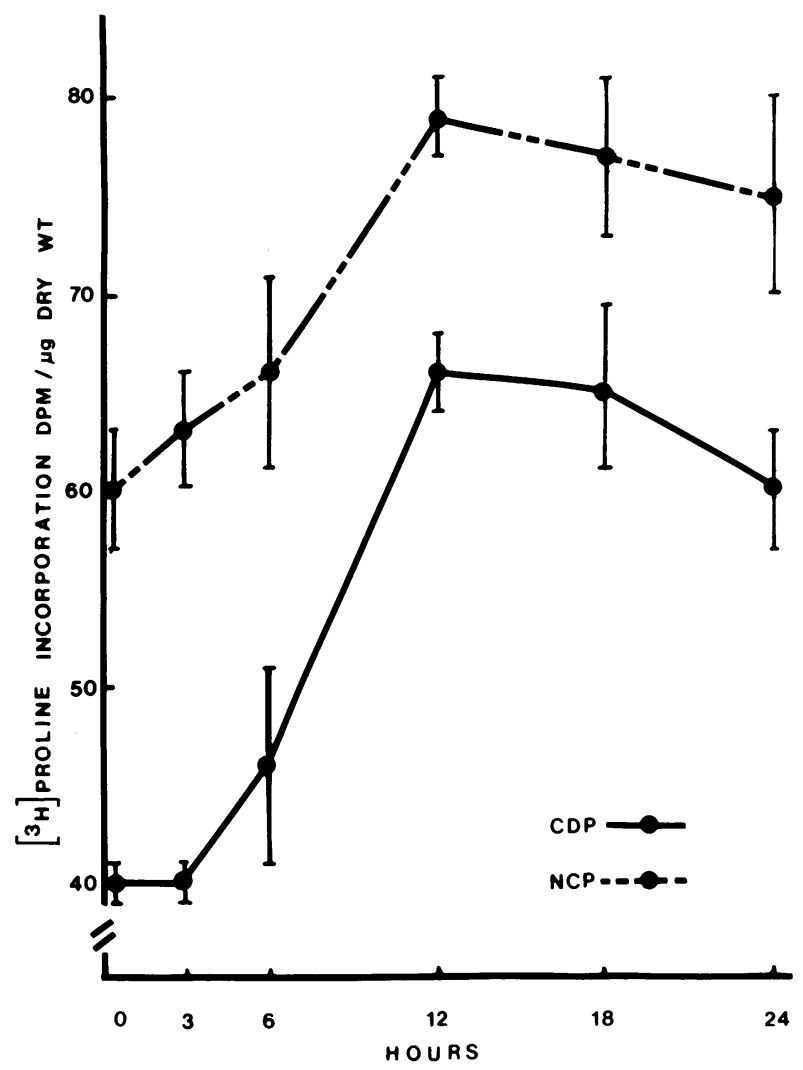

Figure 4 Time-course for the effect of $10 \mathrm{nM}$ IGF I on the incorporation of $\left[{ }^{3} \mathrm{H}\right]$ proline into CDP and NCP. Symbols represent mean values, and vertical lines represent $\mathrm{SE}$ for five half calvaria cultured for $24 \mathrm{~h}$ and pulsed with $\left[{ }^{3} \mathrm{H}\right]$ proline for the last $2 \mathrm{~h}$. IGF I was present only for the indicated times before the end of the culture period. bones was $9.4 \pm 0.9$, and in the nonperiosteal calvarium, $8.2 \pm 0.9$.

Effects of insulin and hormonal interactions of IGF I. After 24 h of culture, insulin caused a dose-dependent stimulation of the incorporation of $\left[{ }^{3} \mathrm{H}\right]$ proline into CDP. A smaller effect was observed on the labeling of NCP so that the percent collagen synthesized was significantly increased. The insulin stimulatory effect was observed at concentrations as low as $1 \mathrm{nM}$ and was over a dose range similar to that observed with IGF I. In contrast, insulin doses as high as $100 \mathrm{nM}-1$ $\mu \mathrm{M}$ were required to stimulate the incorporation of $\left[{ }^{3} \mathrm{H}\right]$ thymidine into acid-insoluble residues, and insulin had only a small and insignificant effect on total bone DNA content (Table V). This differs from the effect of IGF I, which increased the incorporation of $\left[{ }^{3} \mathrm{H}\right]$ thymidine at concentrations as low as $0.01 \mathrm{nM}$ and also increased the bone DNA content. Insulin did not affect the uptake of $\left[{ }^{3} \mathrm{H}\right]$ thymidine into acid-soluble extracts at any of the doses tested (data not shown).

Similar to IGF I, $10 \mathrm{nM}$ insulin increased the incorporation of $\left[{ }^{3} \mathrm{H}\right]$ proline into CDP and increased the percent collagen synthesized in the central portion of the bone or periosteum-free calvarium, without affecting its incorporation in the periosteal segments; but it did not alter the labeling of DNA in either the periosteum or central bone (Table VI). In the experiment partially shown in Table IV, insulin at $1 \mu \mathrm{M}$ increased the incorporation of $\left[{ }^{3} \mathrm{H}\right]$ thymidine to 3,983 $\pm 197 \mathrm{dpm} /$ bone in the periosteum and to $1,056 \pm 97$ $\mathrm{dpm} /$ bone in the periosteum-free calvarium (respective control values were $2,306 \pm 206$ and $439 \pm 50, P<0.01$ ), mimicking the effect observed with IGF I at $30 \mathrm{nM} .100$

TABLE IV

Effect of $10 \mathrm{nM}$ IGF I on the Incorporation of $\left[{ }^{3} \mathrm{H}\right]$ Proline into CDP and NCP and $30 \mathrm{nM}$ IGF I on the Incorporation of $\left[{ }^{3} \mathrm{H}\right]$ Thymidine in Periosteum and Periosteum-free Calvarium

\begin{tabular}{|c|c|c|c|c|}
\hline Treatment & $\mathrm{CDP}$ & NCP & $\begin{array}{l}\text { Collagen } \\
\text { synthesis }\end{array}$ & $\begin{array}{c}{\left[{ }^{3} \mathrm{H}\right] \text { Thymidine }} \\
\text { incorporation }\end{array}$ \\
\hline & \multicolumn{2}{|c|}{ dpm/bone } & $\%$ & dpm/bone \\
\hline \multicolumn{5}{|c|}{ Superior and inferior periosteum } \\
\hline Control & $4,520 \pm 590$ & $9,390 \pm 1,190$ & $8.2 \pm 0.4$ & $2,306 \pm 206$ \\
\hline IGF I & $5,700 \pm 1,250$ & $11,760 \pm 2,010$ & $8.1 \pm 0.4$ & $4,673 \pm 327^{*}$ \\
\hline \multicolumn{5}{|c|}{ Periosteum-free calvarium } \\
\hline Control & $8,410 \pm 480$ & $5,380 \pm 450$ & $22.8 \pm 1.5$ & $439 \pm 50$ \\
\hline IGF I & $13,600 \pm 1,310^{*}$ & $6,210 \pm 750$ & $29.0 \pm 0.6^{*}$ & $1,136 \pm 76^{*}$ \\
\hline
\end{tabular}

Values are means \pm SE for 4-6 half calvaria cultured for $24 \mathrm{~h}$ in the presence or absence of IGF I at $10 \mathrm{nM}$ and pulsed with $\left[{ }^{3} \mathrm{H}\right]$ proline (CDP and NCP) for the last $2 \mathrm{~h}$, or in the presence or absence of IGF I at $30 \mathrm{nM}$ and pulsed with $\left[{ }^{3} \mathrm{H}\right]$ thymidine for the last $60 \mathrm{~min}$ of the culture period. The periosteum was removed by dissection after the incubation was completed. Percent collagen was corrected for the relative abundance of proline in CDP and NCP.

* Significantly different from control, $P<0.02$. 
TABLE V

Effect of Insulin on the Incorporation of $\left[{ }^{3} \mathrm{H}\right]$ Proline into CDP and NCP on Incorporation of $\left[{ }^{3} \mathrm{H}\right] \mathrm{Th}$ !midine, and on DNA Content

in Fetal Rat Calcaria

\begin{tabular}{|c|c|c|c|c|c|c|}
\hline \multicolumn{2}{|c|}{ Treatment } & $\mathrm{CDP}$ & $\mathrm{NCP}$ & $\begin{array}{l}\text { Collagen } \\
\text { synthesis }\end{array}$ & $\begin{array}{l}{ }^{3} \mathrm{H} \mid \text { Thymidine } \\
\text { incorporation }\end{array}$ & DNA content \\
\hline & \multirow[t]{2}{*}{$n .1$} & \multicolumn{2}{|c|}{$d p m / \mu g d r y u t$} & $\%$ & $d p m / \mu g d r y / u t$ & $\mu \mathrm{s} / \mathrm{half}$ calc aria \\
\hline Control & & $49 \pm 2$ & $56 \pm 1$ & $14.0 \pm 0.4$ & $5.9 \pm 0.3$ & $12.2 \pm 1.3$ \\
\hline \multirow[t]{5}{*}{ Insulin } & 0.1 & $48 \pm 3$ & $54 \pm 4$ & $14.1 \pm 0.4$ & & $11.2 \pm 1.3$ \\
\hline & 1 & $75 \pm 2 *$ & $59 \pm 2$ & $19.2 \pm 0.8^{*}$ & $6.1 \pm 0.6$ & $11.2 \pm 0.8$ \\
\hline & 10 & $98 \pm 4^{*}$ & $70 \pm 2 *$ & $20.6 \pm 0.8 *$ & $6.0 \pm 0.4$ & $12.4 \pm 1.5$ \\
\hline & 100 & $114 \pm 8 *$ & $78 \pm 4^{*}$ & $20.9 \pm 1.3^{*}$ & $9.6 \pm 0.9^{*}$ & $12.0 \pm 1.0$ \\
\hline & $1,()(0)$ & $128 \pm 6^{*}$ & $89 \pm 4 *$ & $21.0 \pm 0.6^{*}$ & $10.6 \pm 1.0^{*}$ & $15.1 \pm 1.4$ \\
\hline
\end{tabular}

Values are means $\pm S E$ for five half calvaria cultured for $24 \mathrm{~h}$ in the presence or alsence of insulin and pulsed either with $\left[{ }^{3} \mathrm{H}\right]$ proline (CDP and NCP) for the last $2 \mathrm{~h}$ or with $\left[{ }^{3} \mathrm{H}\right]$ thymidine for the last $60 \mathrm{~min}$ of the culture period. Percent collagen was corrected for the relative abundance of proline in CDP and NCP.

* Significantly different from control, $P<0.01$.

$\mathrm{nM}$ insulin and $30 \mathrm{nM}$ IGF did not have an additive effect on the labeling of CDP or NCP (Table VII).

After $24 \mathrm{~h}$ of culture, cortisol at $100 \mathrm{nM}$ had a small stimulatory effect on the labeling of CDP, without affecting NCP; as a result, there was an increase in the percent of collagen synthesized. Cortisol inhibited the incorporation of $\left[{ }^{3} \mathrm{H}\right]$ thymidine into acid-insoluble residues and decreased the stimulatory effect of IGF I. In contrast, cortisol markedly enhanced the stimulatory effect of IGF I on the incorporation of $\left[{ }^{3} \mathrm{H}\right]$ proline into CDP and on the percent of collagen synthesized ( $\mathrm{Ta}-$ ble VIII).
$\mathrm{T}_{3}$ at $10 \mathrm{nM}$ (data not shown) and $100 \mathrm{nM}$ (Table IX) did not affect the incorporation of labeled proline into CDP or NCP, and did not alter the stimulatory effect of IGF I in calvaria cultured for $24 \mathrm{~h}$. Both doses of $\mathrm{T}_{3}$ increased the incorporation of $\left[{ }^{3} \mathrm{H}\right]$ thymidine into acidinsoluble extracts, and $\mathrm{T}_{3}$ at $100 \mathrm{nM}$ had an additive effect to that of IGF I (Table IX). PTH at $100 \mathrm{nM}$ inhibited the labeling of CDP and opposed the stimulatory effect of IGF I. PTH stimulated the incorporation of $\left[{ }^{3} \mathrm{H}\right]$ thymidine and was additive to IGF I. IBMX (0.1 $\mathrm{mM}$ ) did not alter the labeling of CDP or NCP, but stimulated the incorporation of $\left[{ }^{3} \mathrm{H}\right]$ thymidine; IBMX

TABLE VI

Effect of 10 n.M Insulin on Incorporation of $\left[{ }^{3} H\right]$ Proline into CDP and NCP and on Incorporation of $\left[{ }^{3} H\right]$ Thymidine in Periosteum and Periosteum-free Calcarium

\begin{tabular}{|c|c|c|c|c|}
\hline Treatment & $\mathrm{CDP}$ & $\mathrm{XCP}$ & $\begin{array}{l}\text { Collagen } \\
\text { șinthesis }\end{array}$ & $\begin{array}{c}\left.\right|^{3} \mathrm{H} \mid \mathrm{Th} \text {.midine } \\
\text { incorporation }\end{array}$ \\
\hline & \multicolumn{2}{|c|}{ dpm/bone } & $\%$ & drm/bone \\
\hline \multicolumn{5}{|c|}{ Superior and inferior periosteum } \\
\hline Control & $5,300 \pm 560$ & $12,120 \pm 1,280$ & $7.5 \pm 0.3$ & $3,253 \pm 106$ \\
\hline Insulin & $6,390 \pm 1,340$ & $10,490 \pm 2,230$ & $10.2 \pm 0.5^{*}$ & $3,200 \pm 178$ \\
\hline \multicolumn{5}{|c|}{ Periosteum-free calvarium } \\
\hline Control & $9,110 \pm 400$ & $7,130 \pm 560$ & $19.5 \pm 1.2$ & $957 \pm 92$ \\
\hline Insulin & $21,720 \pm 2,090 *$ & $8,310 \pm 870$ & $32.2 \pm 0.9 *$ & $951 \pm 132$ \\
\hline
\end{tabular}

Values are means $\pm S E$ for five half calvaria cultured for $24 \mathrm{~h}$ in the presence or absence of insulin and pulsed either with $\left[{ }^{3} \mathrm{H}\right]$ proline (CDP and NCP) for the last $2 \mathrm{~h}$ or with $\left[{ }^{3} \mathrm{H}\right]$ thymidine for the last $60 \mathrm{~min}$ of the culture period. The periosteum was removed by dissection after the incubation was completed. Percent collagen was corrected for the relative abundance of proline in CDP and NCP.

* Significantly different from control, $P<0.05$. 
TABLE VII

Effect of $30 \mathrm{nM}$ IGF I and $100 \mathrm{nM}$ Insulin on Incorporation of $\left[{ }^{3} \mathrm{H}\right]$ Proline into CDP and NCP in Fetal Rat Calvaria

\begin{tabular}{llcc}
\hline \multicolumn{1}{c}{ Treatment } & CDP & NCP & $\begin{array}{c}\text { Collagen } \\
\text { synthesis }\end{array}$ \\
\hline & \multicolumn{2}{c}{$d p m / \mu g d r y$ wt } & $\%$ \\
Control & $32 \pm 3$ & $44 \pm 2$ & $12.0 \pm 0.4$ \\
IGF I & $56 \pm 2^{*}$ & $63 \pm 3^{*}$ & $14.1 \pm 0.5^{*}$ \\
Insulin & $73 \pm 6^{*}$ & $63 \pm 5^{*}$ & $17.5 \pm 0.6^{*}$ \\
Insulin + IGF I & $73 \pm 3^{*}$ & $59 \pm 2^{*}$ & $18.7 \pm 0.4^{*}$ \\
\hline
\end{tabular}

Values are means $\pm \mathrm{SE}$ for five half calvaria cultured for $24 \mathrm{~h}$ at the indicated hormonal concentrations and pulsed with $\left[{ }^{3} \mathrm{H}\right]-$ proline for the last $2 \mathrm{~h}$ of the culture period. Percent collagen was calculated after correcting for the relative abundance of proline in CDP and NCP. Results shown in this table were partly obtained from an experiment shown in Table II; data for 24-h control and IGF I are the same.

* Significantly different from control, $P<0.05$.

opposed the stimulatory effect of IGF I on the incorporation of $\left[{ }^{3} \mathrm{H}\right]$ proline into CDP without affecting its effects on $\left[{ }^{3} \mathrm{H}\right]$ thymidine incorporation.

\section{DISCUSSION}

The present studies were undertaken to examine the effects of IGF on bone formation in vitro. IGF I increased the incorporation of $\left[{ }^{3} \mathrm{H}\right]$ thymidine into DNA at concentrations of $0.01-100 \mathrm{nM}$ in cultures of fetal rat calvaria treated for $6-96 \mathrm{~h}$. The effect of IGF I was due to stimulation of DNA synthesis rather than to a change in uptake or the labeling of the precursor pool, because the changes were seen when the medium contained $0.1 \mathrm{mM}$ thymidine and there was no significant effect on uptake into the acid-extractable pool. Further- more, IGF I caused an increase in the DNA content and in the number of mitoses after colcemid arrest. The labeling of DNA, the DNA content, and the number of mitoses in control untreated calvaria were the same immediately after the bones were explanted and throughout the culture period, indicating that cell viability had been preserved and that IGF had specifically stimulated DNA synthesis. A reversible decrease in $\left[{ }^{3} \mathrm{H}\right]$ thymidine incorporation was observed in control bones after $12 \mathrm{~h}$ of culture and appeared to be related to changes in the uptake of the radioactive label, although the mechanism for this phenomenon is presently unknown.

Calvaria cultured in the absence of hormones showed a time-related decrease on the incorporation of $\left[{ }^{3} \mathrm{H}\right]$ proline into CDP up to $12 \mathrm{~h}$ of culture. No changes were observed on collagen content, possibly due to the lower sensitivity of this method. The incorporation of $\left[{ }^{3} \mathrm{H}\right]$ proline into CDP was higher immediately after bone explant, probably because of the in utero effect of multiple hormones and growth factors, which may persist for the first several hours of culture. This is supported by the observation that the labeling of CDP did not continue to decrease after $12 \mathrm{~h}$ of culture. Another explanation for the results may be related to the recent discovery of a growth factor released by cultured calvaria that stimulates DNA synthesis in the absence of hormones but requires the presence of cortisol to stimulate the labeling of CDP (27). Thus, bones in organ culture might provide their own factors to maintain cell replication but require systemic hormones such as cortisol to maintain collagen synthesis.

IGF I increased the incorporation of labeled proline into bone collagen and NCP at $0.1-100 \mathrm{nM}$ in calvaria treated for 12-96 h. The effect on the labeling of CDP did not appear to overcome that observed in control bones after $3 \mathrm{~h}$ of culture, but the latter probably repre-

TABLE VIII

Effect of 10 nM IGF I and $100 \mathrm{nM}$ Cortisol on Incorporation of $\left[{ }^{3} \mathrm{H}\right]$ Proline into CDP and NCP and on Incorporation of $\left[{ }^{3} H\right]$ Thymidine in Fetal Rat Calvaria

\begin{tabular}{lcccc}
\hline \multicolumn{1}{c}{ Treatment } & CDP & NCP & $\begin{array}{c}\text { Collagen } \\
\text { synthesis }\end{array}$ & $\begin{array}{c}\left.{ }^{3} \mathrm{H}\right] \text { Thymidine } \\
\text { incorporation }\end{array}$ \\
\hline & \multicolumn{2}{c}{$d p m / \mu g d r y w t$} & $\%$ & $d p m / \mu g d r y w t$ \\
Control & $35 \pm 1$ & $58 \pm 4$ & $10.2 \pm 0.2$ & $6.7 \pm 0.5$ \\
IGF I & $65 \pm 3^{*}$ & $77 \pm 3^{*}$ & $13.4 \pm 0.2^{*}$ & $8.8 \pm 0.5^{*}$ \\
Cortisol & $49 \pm 2^{*}$ & $58 \pm 3$ & $13.6 \pm 0.2^{*}$ & $3.7 \pm 0.3^{*}$ \\
IGF I + cortisol & $103 \pm 4^{*}+$ & $84 \pm 3^{*}$ & $18.4 \pm 0.7^{*} \ddagger$ & $7.3 \pm 0.6$ \\
\hline
\end{tabular}

Values are means $\pm \mathrm{SE}$ for five half calvaria cultured for $24 \mathrm{~h}$ in the presence or absence of cortisol and IGF I and pulsed either with $\left[{ }^{3} \mathrm{H}\right]$ proline (CDP and NCP) for the last $2 \mathrm{~h}$ or with $\left[{ }^{3} \mathrm{H}\right]$ thymidine for the last $60 \mathrm{~min}$ of the culture period. Percent collagen synthesis was calculated after correcting for the relative abundance of proline in CDP and NCP.

* Significantly different from control, $P<0.02$.

$\ddagger$ Significantly different from IGF I alone, $P<0.01$. 
TABLE IX

Effect of 10 n.M IGF I, 100 n.M T, 100 n.M PTH, and 0.1 mM IBMX on Incorporation of $\left[{ }^{3} \mathrm{H}\right]$ Proline into CDP and NCP and on Incorporation of

$\left[{ }^{3} \mathrm{H}\right]$ Thymidine in Fetal Rat Calvaria

\begin{tabular}{|c|c|c|c|c|}
\hline Treatment & CDP & $\mathrm{NCP}$ & $\begin{array}{l}\text { Collagen } \\
\text { synthesis }\end{array}$ & $\begin{array}{c}{\left[{ }^{3} \mathrm{H} \mid \text { Thymidine }\right.} \\
\text { incorporation }\end{array}$ \\
\hline & \multicolumn{2}{|c|}{$d p m / \mu g d r ! u t$} & $\%$ & $d p m / \mu g d r y w t$ \\
\hline Control & $36 \pm 3$ & $49 \pm 3$ & $11.8 \pm 0.3$ & $5.0 \pm 0.3$ \\
\hline IGF I & $69 \pm 3 *$ & $67 \pm 2 *$ & $16 .(0 \pm 0.7 *$ & $7.8 \pm 0.6^{*}$ \\
\hline $\mathrm{T}_{3}$ & $44 \pm 4$ & $57 \pm 3$ & $12.6 \pm 0.7$ & $8.2 \pm 0.5^{*}$ \\
\hline РTH & $27 \pm 1^{*}$ & $55 \pm 2$ & $8.5 \pm 0.5^{*}$ & $9.8 \pm 0.3^{*}$ \\
\hline IBMX & $38 \pm 2$ & $59 \pm 4$ & $10.7 \pm 0.6$ & $8.0 \pm 0.6^{*}$ \\
\hline $\mathrm{IGF} \mathrm{I}+\mathrm{T}_{3}$ & $59 \pm 5^{*}$ & $72 \pm 3 *$ & $13.1 \pm 0.5 \ddagger$ & $10.2 \pm 0.6^{*}+$ \\
\hline IGF I + PTH & $30 \pm 1 t$ & $58 \pm 2 * t$ & $8.9 \pm 0.3 * t$ & $11.2 \pm 0.7 * t$ \\
\hline IGF I + IBMX & $41 \pm 4 t$ & $60 \pm 3 *$ & $11.2 \pm 0.5^{\ddagger}$ & $9.1 \pm 0.8^{*}$ \\
\hline
\end{tabular}

Values are means $\pm \mathrm{SE}$ for five half calvaria cultured for $24 \mathrm{~h}$ in the presence or absence of the various agents tested and pulsed either with $\left[{ }^{3} \mathrm{H}\right]$ proline (CDP and $\mathrm{NCP}$ ) for the last $2 \mathrm{~h}$ or with $\left[{ }^{3} \mathrm{H}\right]$ thymidine for the last $60 \mathrm{~min}$ of the culture period. Percent collagen synthesis was calculated after correcting for the relative abundance of proline in CDP and NCP.

* Significantly different from control, $P<0.05$.

$\$$ Significantly different from IGF I alone, $P<0.05$.

sents the concerted effect of multiple hormones and nutrients present in utero rather than the effect of a single factor such as IGF I. It seems likely that IGF I acts stimulating collagen synthesis, not by altering proline uptake or pool size, inasmuch as the effect was similar at both high and low medium proline concentrations and it was associated with an increase in total bone collagen content. The IGF I effect is probably due to stimulation of collagen synthesis rather than to inhibition of collagen degradation, since only a small and similar proportion of the newly labeled macromolecular collagen was released in both control and treated cultures. The effect on collagen synthesis could be related to an increase in the number of osteoblasts; however, IGF I could have two independent effects on bone, one on cell replication and another on collagen synthesis. The experiments testing IGF I effects on the periosteum and periosteum-free bone and the histological studies indicate that the IGF I effect on cell replication is generalized. This could include effects on fibroblasts and progenitor cells mostly present in the periosteum as well as effects on the osteoblasts. In contrast, the effect on collagen synthesis is selective to the central bone or periosteum-free calvarium where the osteoblasts (the main collagen-synthesizing cells of bone) predominate $(2.3-26)$. These studies suggest that IGF I has a stimulatory effect on osteoblastic collagen synthesis and a less specific effect on bone cell replication. The doses of IGF I that were found to increase bone DNA, collagen, and noncollagen synthesis were similar to those required to stimulate DNA synthesis and cell proliferation in fibroblasts and sulfate $\left[{ }^{35} \mathrm{~S}\right]$ incorporation in cartilage $(5,8,10)$. Although IGF is largely bound to a carrier protein in serum $(28,29)$, the stimulatory effects on bone formation were observed at doses lower than the reported serum concentrations $(5,28)$, suggesting that they may be physiological.

The present investigations confirm and extend previous observations indicating that insulin stimulates bone collagen and NCP synthesis (2). The stimulatory effect of insulin on bone collagen synthesis was observed at concentrations similar to those found in rat serum (2), was over a dose range similar to that of IGF I, and was limited to the periosteum-free, osteoblasticrich calvarium. In contrast to IGF, insulin increased the incorporation of $\left[{ }^{3} \mathrm{H}\right]$ thymidine only at high concentrations, and had small effects on DNA content.

From the present investigations and from other studies performed on tissues, it appears that the somatomedins regulate both DNA and protein synthesis, whereas insulin only affects protein synthesis and does not have a physiologically important effect on cell replication $(5,8,10,12)$. Insulin and IGF I did not have an additive effect on bone collagen synthesis, suggesting that they may act by the same mechanism. The effects on cell replication would suggest that the insulin effect is mediated by a different mechanism or receptor. This could be an IGF receptor which, as in fibroblasts, is displaced by pharmacological doses of insulin only $(8,12,30,31)$.

Cortisol was found to have a small stimulatory effect on the incorporation of $\left[{ }^{3} \mathrm{H}\right]$ proline into CDP in 24-h cultures, whereas it inhibited DNA synthesis. Cortisol decreased the effect of IGF I on DNA synthesis but 
greatly enhanced the stimulatory effect on bone collagen synthesis, suggesting that the effect of IGF I on collagen synthesis is independent of its effects on cell replication. These results could also be explained if cortisol inhibited the proliferation of a separate, IGF I-unresponsive population of cells, since these studies were performed in cultures containing a mixed cell population. Although in vivo studies have indicated that skeletal growth is inhibited by glucocorticoids (32), in vitro experiments have suggested that glucocorticoids have two different effects on bone formation, one stimulatory - probably related to an effect on the differentiated osteoblast-and another inhibitory-related to the suppression of precursor cell proliferation (13). In addition to the effect of cortisol enhancing the stimulatory effect of IGF I on bone collagen synthesis, this steroid appears to have other important functions in the regulation of skeletal growth, since it is necessary for the synthesis or release of IGF and its carrier protein by the liver (28).

$\mathrm{T}_{3}$ did not affect the labeling of CDP and NCP, confirming previous studies from this laboratory; ${ }^{2}$ however, thyroid hormones might have an indirect effect on bone formation by stimulating the synthesis and release of IGF by the liver $(28,33)$.

The mechanism of action of IGF is not clear at the present time. Because the stimulatory effect of IGF I on CDP labeling was opposed by IBMX, a known inhibitor of cyclic AMP (cAMP) phosphodiesterase (34), and by $\mathrm{PTH}$, believed to act on bone by increasing cAMP $(14,23)$, it is possible that the effect of IGF I on collagen synthesis is mediated by a decrease in CAMP. This mechanism has been proposed for other growth factors (35), but cAMP has not been reported to have a role mediating IGF effects in other tissues or cell systems and the IGF I effects on [ $\left.{ }^{3} \mathrm{H}\right]$ thymidine incorporation in bone were not altered by IBMX.

In conclusion, these studies demonstrate that IGF I stimulates the synthesis of DNA, collagen, and NCP in bone cultures, indicating that IGF I is important in the regulation of appositional growth, in addition to its effects on linear, cartilage-dependent growth. IGF I and insulin are both stimulators of bone collagen synthesis, but IGF I appears to be a physiological regulator of bone DNA synthesis, whereas insulin is not.

\section{ACKNOWLEDGMENTS}

The author wishes to thank Dr. R. E. Humbel for the generous supply of IGF used in these studies; Drs. L. G. Raisz and J. W. Dietrich for helpful advice; Mrs. Sheila Rydziel, Miss Sandra Casinghino, and Miss Donna Petersen for expert technical assistance; and Mrs. Gail Kissell for valuable secretarial help.

This study was supported by grants from the Easter Seal Research Foundation and the Charles H. Hood Foundation.

2 Canalis, E. Unpublished observations.

\section{REFERENCES}

1. Canalis, E. M., R. L. Hintz, J. W. Dietrich, D. M. Maina, and L. G. Raisz. 1977. Effect of somatomedin and growth hormone on bone collagen synthesis in vitro. Metab. Clin. Exp. 26: 1079-1087.

2. Canalis, E. M., J. W. Dietrich, D. M. Maina, and L. G. Raisz. 1977. Hormonal control of bone collagen synthesis in vitro. Effects of insulin and glucagon. Endocrinology. 100: $668-674$.

3. Schwartz, P. L., R. E. Wettenhall, M. A. Troedel, and J. Bornstein. 1970. A long-term effect of insulin on collagen synthesis by newborn rat bone in vitro. Diabetes. 19: $465-466$.

4. Canalis, E., and L. G. Raisz. 1979. Effect of multiplication stimulating activity on DNA and protein synthesis in cultured fetal rat calvaria. Calcif. Tissue Int. 29: 33-39.

5. Rinderknecht, E., and R. E. Humbel. 1976. Polypeptides with nonsuppressible insulin-like and cell growth-promoting activities in human serum: isolation, chemical characterization and some biological properties of forms I and II. Proc. Natl. Acad. Sci. U. S. A. 73: 2365-2369.

6. Rinderknecht, E., and R. E. Humbel. 1978. The amino acid sequence of human insulin-like growth factor I and its structural homology with proinsulin. J. Biol. Chem. 253: 2769-2776.

7. Rinderknecht, E., and R. E. Humbel. 1976. Amino-terminal sequences of two polypeptides from human serum with nonsuppressible insulin-like and cell growth-promoting activities: evidence for structural homology with insulin chain. Proc. Natl. Acad. Sci. U. S. A. 73: 43794381 .

8. Zapf, J., E. Rinderknecht, R. E. Humbel, and E. R. Froesch. 1978. Nonsuppressible insulin-like activity (NSILA) from human serum: recent accomplishments and their physiological implications. Metab. Clin. Exp. 27: 180)3-1828.

9. Van Wyk, J. J., M. E. Svoboda, and L. E. Underwood. 1980. Evidence from radioligand assays that somatomedin-C and insulin-like growth factor-I are similar to each other and different from other somatomedins.J. C.lin. Endocrinol. Metab. 50: 206-208.

10. Zapf, J., E. Schoenle, and E. R. Froesch. 1978. Insulinlike growth factors I and II: some biological actions and receptor binding characteristics of two purified constituents of nonsuppressible insulin-like activity of human serum. Eur. J. Biochem. 87: 285-296.

11. Haselbacher, G. K., and R. E. Humbel. 1976. Stimulation of ornithine decarboxylase activity in chick fibroblasts by nonsuppressible insulin-like activity (NSILA), insulin and serum. J. Cell. Physiol. 88: 239-246.

12. Rechler, M. M., J. M. Podskalny, I. D. Goldfine, and C. A. Wells. 1974. DNA synthesis in human fibroblasts: stimulation by insulin and by nonsuppressible insulin-like activity (NSILA). J. Clin. Endocrinol. Metab. 39: 512-521.

13. Dietrich, J. W., E. M. Canalis, D. M. Maina, and I. (; Raisz. 1979. Effects of glucocorticoids on fetal rat bone collagen synthesis in vitro. Endocrinology. 104: 715-721.

14. Dietrich, J. W., E. M. Canalis, D. M. Maina, and L. (; Raisz. 1976. Hormonal control of bone collagen synthesis in vitro. Effects of parathyroid hormone and calcitonin. Endocrinology. 98: 943-949.

15. Halme, J., J. Vitto, K. I. Kivirikko, and L. Saxen. 1972. Effect of triiodothyronine on the metabolism of collagen in cultured embryonic bones. Endocrinology. 90: 14761482.

16. Bingham, P. J.. and L. G. Raisz. 1974. Bone growth in organ culture: effects of phosphate and other mutrients on bone and cartilage. Calcif. Tissue Res. 14: 31-48. 
17. Kissane, J. M., and E. Robbins. 1958. The fluorometric measurement of deoxyribonucleic acid in animal tissues with special reference to the central nervous system. $J$. Biol. Chem. 233: 184-188.

18. Fujimoto, W., J. Teague, and R. H. Williams. 1977. Fibroblast monolayer cultures in scintillation counting vials: metabolic and growth experiments using radioisotopes and microfluorometric DNA assay. In Vitro. 13: 237-243.

19. Peterkofsky, B., and R. Diegelmann. 1971. Use of a mixture of proteinase-free collagenases for the specific assay of radioactive collagen in the presence of other proteins. Biochemistry. 10: 988-994.

20. Peterkofsky, B. 1972. The effect of ascorbic acid on collagen polypeptide synthesis and proline hydroxylation during the growth of cultured fibroblasts. Arch. Biochem. Biophys, 152: 318-328.

21. Cheng, P. H. 1969. An improved method for the assay of hydroxyproline in rat skin. J. Invest. Dermatol. 53: 112115.

22. Neuman, R. E., and M. A. Logan. 1950. The determination of hydroxyproline. J. Biol. Chem. 184: 299-306.

23. Peck, W. A., J. K. Burks, J. Wilkins, S. V. Rodan, and G. A. Rodan. 1977. Evidence of preferential effects of parathyroid hormone, calcitonin and adenosine on bone and periosteum. Endocrinology. 100: 1357-1364.

24. Peck, W. A., S. J. Birge, and S. A. Fedak. 1964. Bone cells: biochemical and biological studies after enzymatic isolation. Science (Wash. D. C.). 146: 1476-1477.

25. Wong, G. L., and D. V. Cohn. 1975. Target cells in bone for parathormone and calcitonin are different. Enrichment for each cell type by sequential digestion of mouse calvaria and selective adhesion to polymeric surfaces. Proc. Natl. Acad. Sci. U. S. A. 72: 3167-3171.

26. Yagiela, J. A., and D. W. Woodbury. 1977. Enzymatic isolation of osteoblasts from fetal rat calvaria. Anat. Rec. 188: 287-306.

27. Canalis, E., W. A. Peck and L. G. Raisz. 1980. An autologous growth factor which stimulates DNA and collagen synthesis in cultured fetal rat calvaria. Science (Wash. D. C.). In press.

28. Schalch, D. S., U. E. Heinrich, B. Draznin, C. J. Johnson, and L. L. Miller. 1979. Role of the liver in regulating somatomedin activity: hormonal effects on the synthesis and release of insulin-like growth factor and its carrier protein by the isolated perfused rat liver. Endocrinology. 104: $1143-1151$.

29. Heinrich, U. E., D. S. Schalch, J. G. Koch, and C. J. Johnson. 1978. Nonsuppressible insulin-like activity (NSILA). II. Regulation of serum concentrations by growth hormone and insulin. J. Clin. Endocrinol. Metab. 46: 672678.

30. Morell, B., and E. R. Froesch. 1973. Fibroblasts as an experimental tool in metabolic and hormone studies. II. Effects of insulin and nonsuppressible insulin-like activity (NSILA-S) on fibroblasts in culture. Eur. J. Clin. Invest. 3: $119-123$.

31. Zapf, J., M. Mader, M. Waldvogel, D. S. Schalch, and E. R. Froesch. 1975. Specific binding of nonsuppressible insulinlike activity to chicken embryo fibroblasts and to a solubilized fibroblast receptor. Arch. Biochem. Biophys. 168: $630-637$.

32. Loeb, J. N. 1976. Corticosteroids and growth. N. Engl. J. Med. 295: 547-552.

33. Burstein, P. J., B. Draznin, C. J. Johnson, and D. S. Schalch. 1979. The effect of hypothyroidism on growth, serum growth hormone, the growth hormone-dependent somatomedin, insulin-like growth factor and its carrier protein in rats. Endocrinology. 104: 1107-1111.

34. Kramer, G. L., J. E. Garst, S. S. Mitchell, and J. N. Wells. 1977. Selective inhibition of cyclic nucleotide phosphodiesterases by analogues of 1-methyl-3-isobutylxanthine. Biochemistry. 16: 3316-3321.

35. Hollenberg, M. D., and P. Cuatrecasas. 1973. Epidermal growth factor: receptors in human fibroblasts and modulation of action by cholera toxin. Proc. Natl. Acad. Sci. U. S. A. 70: $2964-2968$. 